\title{
Phacotus lenticularis content in carbonate sediments and epilimnion in four German hard-water lakes
}

\author{
Sebastian Lenz, ${ }^{1 *}$ Nathalie Dubois,,${ }^{2,3}$ Juergen Geist, ${ }^{1}$ Uta Raeder ${ }^{1}$ \\ ${ }^{1}$ School of Life Sciences Weihenstephan, Aquatic Systems Biology Unit, Limnological Research Station Iffeldorf, Technical \\ University of Munich, Germany; ${ }^{2}$ Eawag, Swiss Federal Institute of Aquatic Science and Technology, Surface Waters Research and \\ Management, Dübendorf, Switzerland; ${ }^{3}$ ETH Zurich, Department of Earth Sciences, Zürich, Switzerland
}

\begin{abstract}
Autochthonous calcite precipitation is an important process for C-fixation in hard-water lakes, which is mainly induced by the photosynthesis of planktonic microorganisms. Among these, the widespread calcifying green alga Phacotus lenticularis (Ehrenberg) Diesing contributes to biogenic calcite precipitation in temperate regions. Its role in carbonate precipitation needs to be investigated, because there are no studies dedicated to the quantitative contribution of Phacotus shells to long term carbonate sequestration in hard-water lake sediments. In order to fill this gap, the Phacotus shell content in the sediments of four German hard-water lakes was determined and compared to the fraction of Phacotus shells in the total suspended autochthonous calcite of the euphotic zone. It was found that the Phacotus shells contributed at least $10 \%$ to the autochthonous carbonate precipitation in the upper water column in three investigated lakes. During a Phacotus mass occurrence with a cell density of $1.8 \times 10^{6} \mathrm{Ind} \mathrm{L}^{-1}$ in Lake Hopfensee, even $59 \%$ of the $3.6 \mathrm{mg} \mathrm{L}-1$ total carbonate concentration consisted of Phacotus shells. In contrast to this high amount, the topmost basinal sediment contained a Phacotus shell content between 80 and 36,252 individuals per mg dry sediment, representing only $0.02 \%$ to $2.28 \%$ of the total carbonate sediment content. In a gravity core from Lake Grosser Ostersee, dating back 150 years, the Phacotus shell content was continuously below $0.24 \%$ whereas the shell diameters remained equal to those of living individuals found in the water column proving that Phacotus shells are capable to persist in the sediment after deposition. A main reason for the large discrepancy between Phacotus shell abundance in the euphotic zone and in sediment was found to be the gross authigenic carbonate precipitation, which dilutes the sedimenting Phacotus shells that accumulate exclusively during short and intensive population peaks in summer. Additionally, dissolution of the carbonate shells during sedimentation was proven to be a relevant factor in Lake Igelsbachsee by means of reducing the number of Phacotus shells reaching the lake bottom. These facts explain that short-term high Phacotus carbonate contents of the total suspended carbonate in the water column do not mirror the contribution of Phacotus shells in the sedimentary record.
\end{abstract}

\section{INTRODUCTION}

Autochthonous calcite precipitation induced by primary production is a common process in alkaline hardwater lakes (Dittrich et al., 2004; Müller et al., 2006; Stabel, 1986). Similarly, calcite precipitation occurs in surface waters as a result of the warming effects. This phenomenon is also well understood and has been applied in

Corresponding author: s.lenz@tum.de

Key words: Microfossil; calcifying green alga; quantitative sediment analysis; autochthonous calcite precipitation; calcite shells; hard-water lake.

Edited by: Diego Fontaneto, CNR-IRSA Verbania, Italy.

Received: 26 October 2019.

Accepted: 11 March 2020

This work is licensed under a Creative Commons Attribution NonCommercial 4.0 License (CC BY-NC 4.0).

${ }^{\circ}$ Copyright: the Author(s), 2020

Licensee PAGEPress, Italy

J. Limnol., 2020; 79(2): 187-197

DOI: 10.4081/jlimnol.2020.1945 quantitative approaches determining fine sediment deposition (Auerswald and Geist, 2018). Biological calcite precipitation involves formation of carbonate shells by the planktonic calcifying phytoflagellate Phacotus lenticularis (Ehrenberg) Diesing (1866) (Guiry 2019). Phacotus lenticularis, hereinafter abbreviated Phacotus, is a widespread alga that lives in temperate, subtropical and tropical regions and occurs worldwide in lime-rich alkaline stagnant inland waters (Schlegel et al., 1998).

The epilimnion Phacotus substantially contributes to the total suspended epilimnetic calcite precipitation, particularly during mass developments, due to its two lenslike calcite shells. The normal contributions ranges from $5-10 \%$ and can sometimes reach 100\% (Koschel and Raidt, 1988; Krienitz et al., 1993; Gruenert and Raeder, 2014; Lenz et al., 2018). Phacotus is also supposed to be a significant source of carbonate in lake sediments as suggested by Kelts and Hsü (1978). Sedimentary records prove that Phacotus shells can be preserved and form dominating sediment fractions. The oldest reported occurrences of the calcareous shells were found in an early Miocene (126-138 ka BP) fresh water deposit in Öhningen in southwest Germany and in a middle Miocene (115$126 \mathrm{ka}$ BP) limestone deposit, which had a 'particularly high occurrence' of Phacotus shells that it was referred to as 'Phacotus-Kalk', in Jutland, Denmark (Lagerheim, 
1902). In addition, a sediment core from the early Dryas (13-11 ka BP) found in south Argentina contained sediments, in which the calcite fraction almost exclusively consisted of Phacotus shells (Haberzettl et al., 2007; Jouve et al., 2013). Müller and Oti (1981) introduced a summary and a detailed description of the documented fossil Phacotus occurrences in Eurasia, including a fossil Phacotus occurrence in brackish sediments from the Miocene Ries crater (72-116 ka BP) in south Germany. However, all these findings offer only qualitative descriptions of the Phacotus records.

This study aimed to quantitatively evaluate the role of Phacotus in lacustrine calcite precipitation based on the quantitative assessment of the Phacotus shell fraction in the sediment and the water body of four German lakes. The percentage of suspended Phacotus shells in the total suspended autochthonous calcite in the epilimnion was determined and compared to the Phacotus shell amount in the corresponding sediment deposits. It was hypothesised that Phacotus shells significantly contribute to the lacustrine 'carbonate sequestration', because carbon is mineralised as carbonate and sequestered over long geologic timescales.

\section{Study site}

Four Bavarian lakes (Tab. 1) with documented occurrences of Phacotus in the last ten years (2005-2015) were investigated: Lake Grosser Ostersee (GOS), Lake Abtsdorfer See (ABS), Lake Igelsbachsee (IGS), and Lake Hopfensee (HOP) (Fig. 1). They are all stratified natural hard-water lakes located in the pre-alpine basin in south Bavaria, Germany, except IGS, which is a Carich artificial reservoir lying in a basin of late Triassic quartz sandstones surrounded by Jurassic carbonates. All other lakes have carbonate dominated catchments, are fed with alkaline water from the Northern Limestone Alps, and are a part of an open quaternary aquifer of predominantly fluvioglacial sediments with intercalated basal moraine tills that overlay a Tertiary sandstone aquitard.

\section{METHODS}

Water samples for Phacotus abundance and total epilimnetic particulate calcite analysis (Fig. 2) were collected on a weekly basis from the surface water (0-7 $\mathrm{m}$ depth) at the deepest point of each lake following the method described by Lenz et al. (2018). Depth profiles of water temperature and $\mathrm{pH}$ were measured in situ with a WTW MPP 930 mulitprobe. The concentrations of $\mathrm{Ca}^{2+}$ in solution were determined following the method described in Gruenert and Raeder (2014). Particulate $\mathrm{CaCO}_{3}$ concentration was measured using infrared $\mathrm{CO}_{2}$ analysis on a Saxon Junkalor Infralyt 50 gas analyser (Lenz et al., 2018), and the plankton abundance was determined with an inverted microscope Leitz Labovert at 200× based on the method mentioned in Utermöhl (1958).

A scientific diver used a tube from a PVC Uwitec gravity corer to collect samples from the surface sediment, i.e. the topmost material from the deepest point of each lake. The upper $4 \mathrm{~cm}$ of the composite samples were examined, in order to obtain a representative mean value over several years to diminish the effects of annual variance of Phacotus populations and to include carbonate dissolution in the oxic part of the sediment. An aliquot of each sample was suspended in $10 \mathrm{~mL}$ buffered suspension liquid $\left(\mathrm{NH}_{3}+\mathrm{H}_{2} \mathrm{O}\right.$ ) with a $\mathrm{pH}$ of $\geq 8.5$ (Bollmann et al., 1999). The sediment was mildly dried and carefully homogenised in a mortar. A $0.50 \mathrm{mg}$ homogenised sample mixed with $2 \mathrm{~mL}$ of the suspension liquid was transferred into an Eppendorf tube. Next, $0.50 \mathrm{mg}$ of borosilicate microspheres (ThermoFisher Scientific \#9015; Waltham, MA, USA) were used as calibration standard, and the disaggregation of the carbonate aggregates was conducted using a BAndelin Sonorex TK52 (Berlin, Germany) ultrasound bath (one minute, $150 \mathrm{~W}, 35 \mathrm{kHz}$ ) following the method used by Bordiga et al. (2015). Finally, the sample was mixed using a CHS Vortex homogeniser (Praha, Czech Republic). A 50- $\mu \mathrm{L}$ sample of the suspension was obtained during the mixing and placed into the centre of a circular coverslip using a laboratory pipette according to the 'drop' method (Bordiga et al., 2015; Koch and

Tab. 1. Limnologic characteristics and sampling locations at the deepest point of the examined hard-water lakes.

\begin{tabular}{|c|c|c|c|c|}
\hline & Gr. Ostersee & Abtsdorfersee & Igelsbachsee & Hopfensee \\
\hline Trophic state & Oligotrophic & Mesotrophic & Mesotrophic & Eutrophic \\
\hline Circulation type & Dimictic & Dimictic & Polymictic & Dimictic \\
\hline Surface area $[\mathrm{ha}]$ & 118 & 78 & 72 & 186 \\
\hline Max. depth [m] & 29.7 & 20.0 & 11.5 & 10.4 \\
\hline Volume $\left[100 \mathrm{~m}^{3}\right]$ & 14.0 & 9.4 & 3.9 & 8.9 \\
\hline Calc. residence time $[\mathrm{d}]$ & 247 & 252 & $-/-$ & 128 \\
\hline Coordinates (WGS 84) & $\begin{array}{l}47^{\circ} 47^{\prime} 25^{\prime \prime} \\
011^{\circ} 18^{\prime} 07^{\prime}\end{array}$ & $\begin{array}{c}47^{\circ} 54^{\prime} 35^{\prime \prime} \\
012^{\circ} 54^{\prime} 22^{، ~}\end{array}$ & $\begin{array}{l}49^{\circ} 08^{\prime} 45^{\prime \prime} \\
010^{\circ} 54^{\prime} 13^{\prime \prime}\end{array}$ & $\begin{array}{c}47^{\circ} 36^{\prime} 06^{\prime \prime} \\
010^{\circ} 40^{\prime} 46^{\prime \prime}\end{array}$ \\
\hline
\end{tabular}




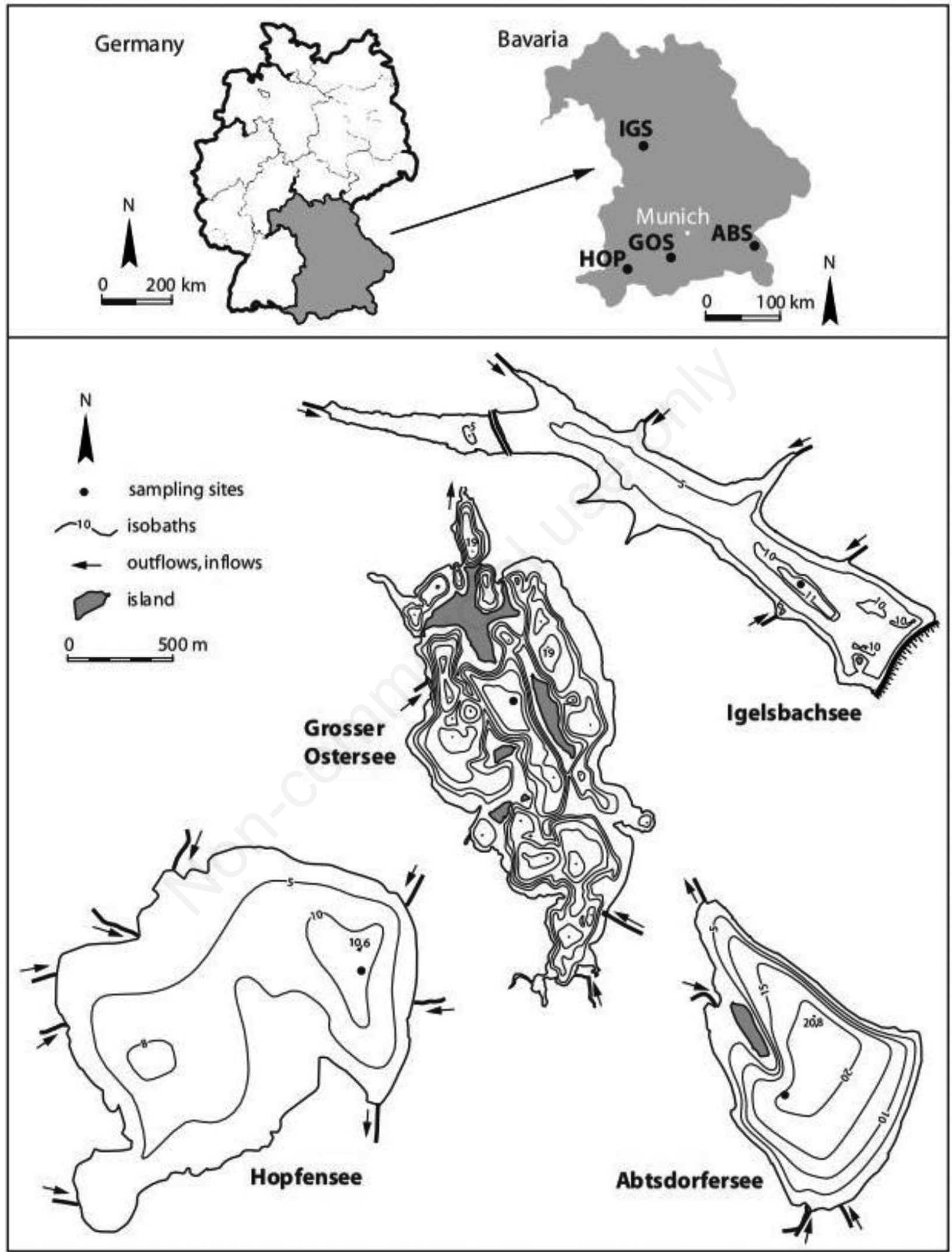

Fig. 1. Locations of the study sites in Bavaria, Germany: bathymetry and sampling points at Lake Igelsbachsee (IGS), Lake Grosser Ostersee (GOS), Lake Hopfensee (HOP), and Lake Abtsdorfersee (ABS). 
Young, 2007). This process was replicated five times for each sample. The exact mass of sediment ( $\mathrm{m}_{\text {sed DG_soll }}$ ) on the coverslips was calculated from the total amount of microspheres on them. Shell number was visually determined for each coverslip using light-microscopy with polarised light at $200 \times$ magnification. Intact Phacotus individuals were counted as two shells whereas single shells were counted as half individuals. Rare broken shells were counted as an entire shell, if the fragment was more than half of a shell to avoid overestimation of the Phacotus shell abundance. The Phacotus shell fraction in the sediment $\mathrm{w}_{\text {Phacotus }}[\%]$ was calculated using the product of shell number and lake specific mean shell mass relative to the total sediment and carbonate mass on the entire coverslip, respectively, according to the method described by Lenz et al. (2018).

A sediment core from GOS (GOS-07) was selected for further analysis and dating. The core samples were collected using a UWITEC gravity corer (Mondsee, Austria) at the deepest point of the lake in 2017. The core was split lengthwise, lithologically described, and subsequently sub-sampled at $1 \mathrm{~cm}$ resolution. One half of the core was used for dating, elemental analysis, and sediment size distribution at Eawag in Dübendorf, Switzerland. The freezedried samples were carefully homogenised and dated through ${ }^{137} \mathrm{Cs}$ and ${ }^{210} \mathrm{~Pb}$ activity measurements using a Canberra Ge well detector (San Ramon, CA, USA) ac- cording to the methods described in Appleby (2001) and McGowan et al. (2015). The sedimentation rate of ${ }^{210} \mathrm{~Pb}$ was determined after subtracting the ${ }^{226} \mathrm{Ra}$ activity using a constant flux sedimentation rate model. The elemental analysis of total carbon (TC) and total nitrogen (TN) was conducted using a Hekatech Euro EA 300 elemental analyser (Wegberg, Germany). Total inorganic carbon (TIC) was determined using a UIC Coulometer CM 5015 (Joliet, IL, USA). Total organic carbon (TOC) was calculated by subtraction of TIC from TC. The carbonate content $\left(\mathrm{CaCO}_{3}\right)$ was calculated from TIC through multiplication by the ratio of the molecular weights of $\mathrm{CaCO}_{3}$ and $\mathrm{C}\left(100.09 \mathrm{~g} \mathrm{~mol}^{-1}\right.$ and $12.01 \mathrm{~g} \mathrm{~mol}^{-1}$, respectively). Total carbon accumulation rate $\mathrm{R}_{\text {acc TC }}\left[\mathrm{g} \mathrm{cm}^{-2} \mathrm{a}^{-1}\right]$ was derived from the total carbon fraction TC [wt \%] of the sediment mass accumulation rate $\mathrm{R}_{\mathrm{acc} \mathrm{sm}}\left[\mathrm{g} \mathrm{cm}^{-2} \mathrm{a}^{-1}\right]$ (eq. 1). $R_{\text {acc sm }}$ of each sample was individually calculated through the multiplication of sediment density $\rho_{\text {sed }}\left[\mathrm{g} \mathrm{cm}^{-}\right.$ $\left.{ }^{3}\right]$ by the sedimentation rate $\mathrm{R}_{\mathrm{sed}}\left[\mathrm{cm} \mathrm{a}^{-1}\right]$ (eq. 2 ).

$\mathrm{R}_{\text {acc TC }}=\mathrm{R}_{\text {acc sm }} *(\mathrm{TC})$
$\mathrm{R}_{\text {acc sm }}=\rho_{\text {sed }} * \mathrm{R}_{\text {sed }}$

The particle size analysis was performed on wet unprocessed sediment from the sediment core (GOS-06) that was obtained at the same location and date as GOS-07. It was also stored and divided in the exact same manner. To

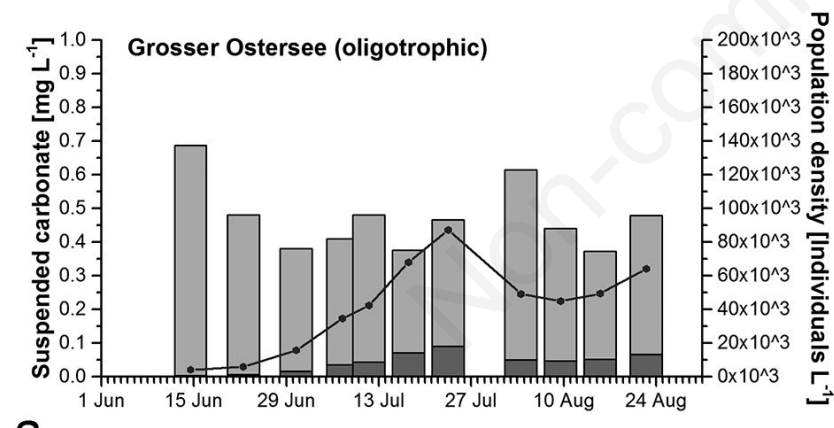

a

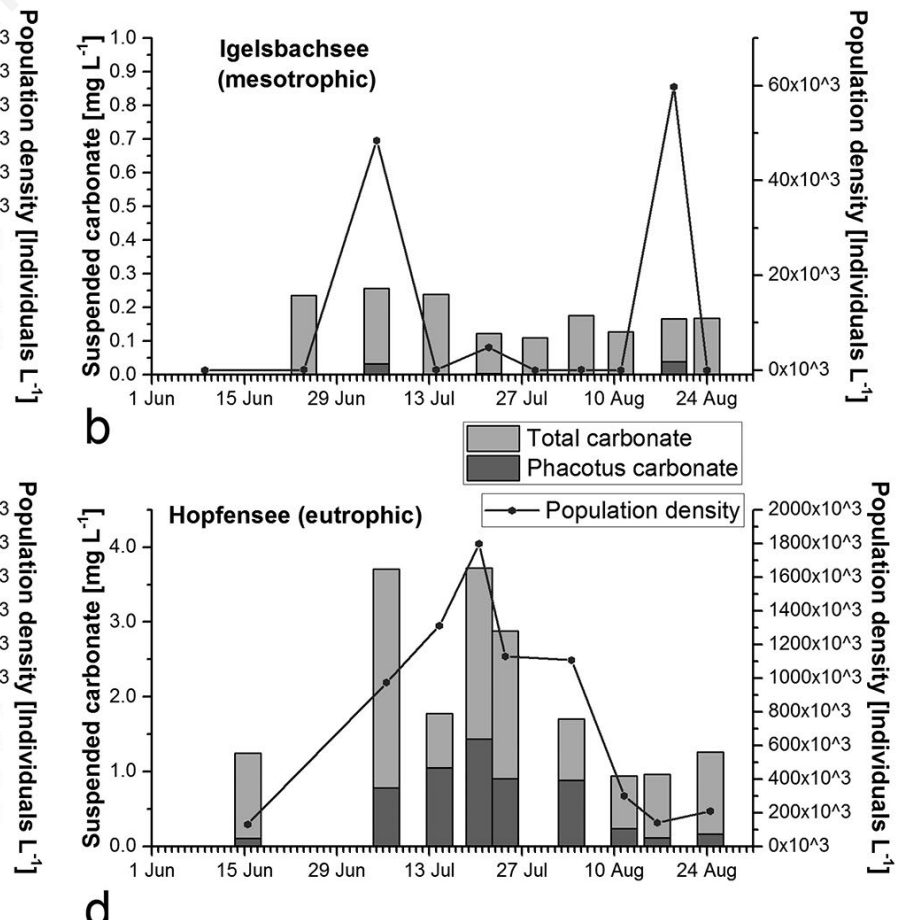

C

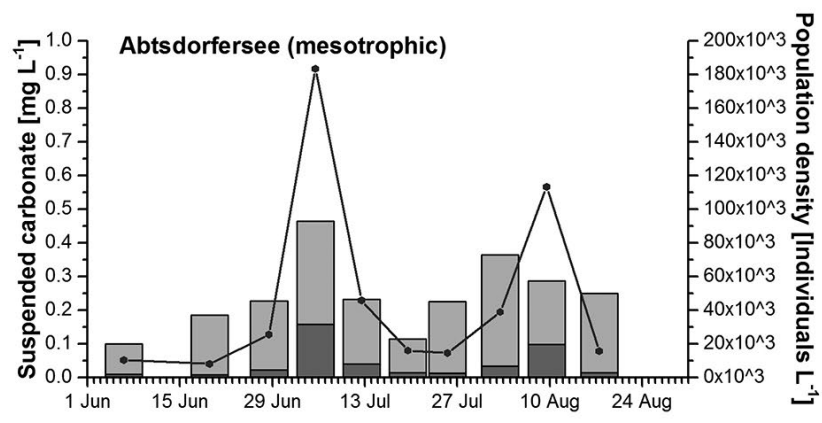

Fig. 2. Total suspended epilimnetic carbonate (white bars) and Phacotus carbonate fraction (grey bars) with the corresponding Phacotus population density (data points) during the growth period in the summer of 2016. 
ensure comparability, both cores were lithologically described and cross-correlated based on their lithological description. Samples were disaggregated using Na-Pyrophosphate and ultra sound, and then particle size analysis was conducted with a Malvern Mastersizer 2000 (Malvern, UK).

The second half of GOS-07 was used to determine the Phacotus shell content using the previously described method for surface sediment samples. Additionally, Phacotus shell diameter measurements were performed on 136 evenly distributed shells over the complete sediment core using Kappa Opto-Electronics \& AccuSoft (Gleichen, Germany) camera software Kappa ImageBase (2007). Micrographs were analysed with FiJi ImageJ image analysis software (Rasband, 2016) using two perpendicular diameter measurements, and the selected shells were examined under scanning electron microscope (SEM) at the Limnological Research Station of TU Munich, Germany, in order to detect potential dissolution features.

\section{RESULTS}

\section{Suspended carbonate in lake water and Phacotus fraction}

The amount and temporal variation of total suspended carbonate in the lake water and the contributing Phacotus fraction measured during the period of the strongest $\mathrm{Pha}$ cotus growth, which took place between June and August 2016, were found to be different in the four investigated lakes (Fig. 2). In the eutrophic HOP, the total carbonate concentration reached its highest level at $3.5 \mathrm{mg} \mathrm{L}^{-1}$. In the other three lakes, the values were always below 0.7 $\mathrm{mg} \mathrm{L}^{-1}$. Furthermore, in HOP during a Phacotus bloom, the cell density was $1.8 \times 10^{6} \mathrm{Ind} \mathrm{L}^{-1}$. The Phacotus carbonate temporal contribution to the total suspended carbonate in the epilimnion was measured during this period to be $59 \%$. In ABS, two Phacotus growth peaks were observed with a maximum cell density of 183,400 Ind L $^{-1}$ during the first peak when Phacotus represented 34\% of the total suspended carbonate. In GOS, the first population peak had a lower maximum cell density of 84,200 Phacotus $\mathrm{L}^{-1}$ at the end of June, during which the Phacotus shells contributed $19 \%$ to the total suspended carbonate in the epilimnion.

In HOP, ABS, and GOS, the $\mathrm{pH}$ values and conductivities of the lake water indicated permanent carbonate oversaturation throughout the entire depth of the water column (Tab. 2). These conditions did not prevail in IGS, where the actual amount of Phacotus could not be accurately recorded, due to the dissolution of Phacotus shells caused by the low $\mathrm{Ca}^{2+}$ concentrations. This was observed by counting Phacotus shells of two identical plankton samples at different times. Cell densities measured immediately after the fieldwork were found to be around $5 \times$ $10^{4}$ Ind L $\mathrm{L}^{-1}$, while Phacotus shells disappeared after one month. Therefore, IGS represents a lake with Phacotus population in the water column, but with almost no sedimentary Phacotus records, because the shells dissolve before being preserved in the sediment.

\section{Surface sediment analysis}

Surface sediment analysis revealed that the four lakes had significantly different total carbonate contents (Tab. 2).

Tab. 2. Phacotus lenticularis (P.l.) fraction in surface sediment $(0-4 \mathrm{~cm})$ and surface water $(0-7 \mathrm{~m})$ with the corresponding epilimnetic physical chemical water conditions (standard deviation indicated between brackets).

\begin{tabular}{|c|c|c|c|c|}
\hline & Gr. Ostersee & Abtsdorfersee & Igelsbachsee & Hopfensee \\
\hline \multicolumn{5}{|c|}{ Sediment from deepest point of the lake $(0-4 \mathrm{~cm})$ : } \\
\hline P.l. shells [Individuals $\mathrm{mg}^{-1}$ ] & $3.255(1.074)$ & $24.401(603)$ & $80(22)$ & $36.252(1.539)$ \\
\hline P.l. fraction sediment $[\%]^{*}$ & $0.15(0.06)$ & $1.05(0.03)$ & $0.00(0.00)$ & $1.45(0.06)$ \\
\hline $\mathrm{CaCO}_{3}$ fraction sediment $[\%]$ & 88.8 & 42.8 & 12.5 & 63.6 \\
\hline $\begin{array}{l}\text { P.l. fraction in total carbonate } \\
\text { sediment }[\%]^{*}\end{array}$ & $0.16(0.06)$ & $2.45(0.06)$ & $0.02(0.01)$ & $2.28(0.10)$ \\
\hline \multicolumn{5}{|c|}{ Suspended carbonate from water column ( $0-7 \mathrm{~m})$ : average values of water, June-August 2016} \\
\hline $\begin{array}{l}\text { Mean } P . l \text {. fraction in suspended } \\
\text { carbonate in water }[\%]^{*}\end{array}$ & $9.9(6.1)$ & $13.9(10.6)$ & $4.3(7.9)$ & $29.0(16.9)$ \\
\hline Water temp. $\left({ }^{\circ} \mathrm{C}\right)$ & $17.4(4.7)$ & $15.5(5.2)$ & $20.9(2.7)$ & $17.3(2.8)$ \\
\hline $\mathrm{pH}$ value & $8.2(0.2)$ & $7.9(0.4)$ & $8.6(0.5)$ & $8.2(0.4)$ \\
\hline $\mathrm{Ca}^{2+}$ conc. $\left(\mathrm{mg} \mathrm{L}^{-1}\right)$ & 69.2 & 78.2 & 37.6 & 69.3 \\
\hline $\mathrm{TP}\left(\mu \mathrm{g} \mathrm{L}^{-1}\right)$ & $>8.2$ & $>17.4$ & $>25$ & $>35$ \\
\hline Secci depth (m) & $3.3(0.6)$ & $1.1(0.2)$ & $3.0(0.6)$ & $1.1(0.3)$ \\
\hline
\end{tabular}


This strongly affected the Phacotus fraction of the total carbonate sediment with Phacotus shell content ranging from 80 (IGS) to 36,252 (HOP) individuals per mg dry sediment [Ind $\mathrm{mg}^{-1}$ ] in the topmost $4 \mathrm{~cm}$ of basinal sediment. This represents total Phacotus carbonate content of $0.02 \%$ and $2.28 \%$ in IGS and HOP, respectively. The other two lakes (GOS and ABS) had intermediate Phacotus shell contents of 3255 and 24,401 shells per mg dry sediment, respectively, and the Phacotus fraction contributed $0.16 \%$ and $2.45 \%$, respectively, to the total carbonate in the sediment.

\section{Sediment core from Lake Grosser Ostersee}

The age model (Fig. 3) is based on ${ }^{137}$ Cs-activity measurements and confirmed by the sedimentation rate derived from the ${ }^{210} \mathrm{~Pb}$-activity measurements. In the topmost section, $\mathrm{R}_{\text {sed }}$ was determined through the interpola- tion between the surface (2016), the ${ }^{137} \mathrm{Cs}$ peaks (1963 and 1986), and the first signal of ${ }^{137} \mathrm{Cs}$ activity (1954). The time determination for 1963 was set at the depth of 11.5 $\mathrm{cm}$ below the actual ${ }^{137} \mathrm{Cs}$-activity peak, because the coherent lamination and varve thickness were better fitted with the rest of the sediment core, suggesting that Cs probably has been remobilised in the sediment. In the section from $1954(13.5 \mathrm{~cm})$ to $1925(19.5 \mathrm{~cm})$, the age of the samples was determined by counting the biochemical varves downwards. In the non-laminated section above $19.5 \mathrm{~cm}$, the ${ }^{210} \mathrm{~Pb}$ a $0.21 \mathrm{~cm} \mathrm{a}^{-1}$ sedimentation rate was used, resulting in a basal age of $\sim 150$ a. As sampling was conducted in $1.0 \mathrm{~cm}$ steps, every sample represented four to five years.

The core was subdivided into three lithological units: A (0-10 cm), B (10-19 cm), and C (19-31.5 cm) (Fig. 4).

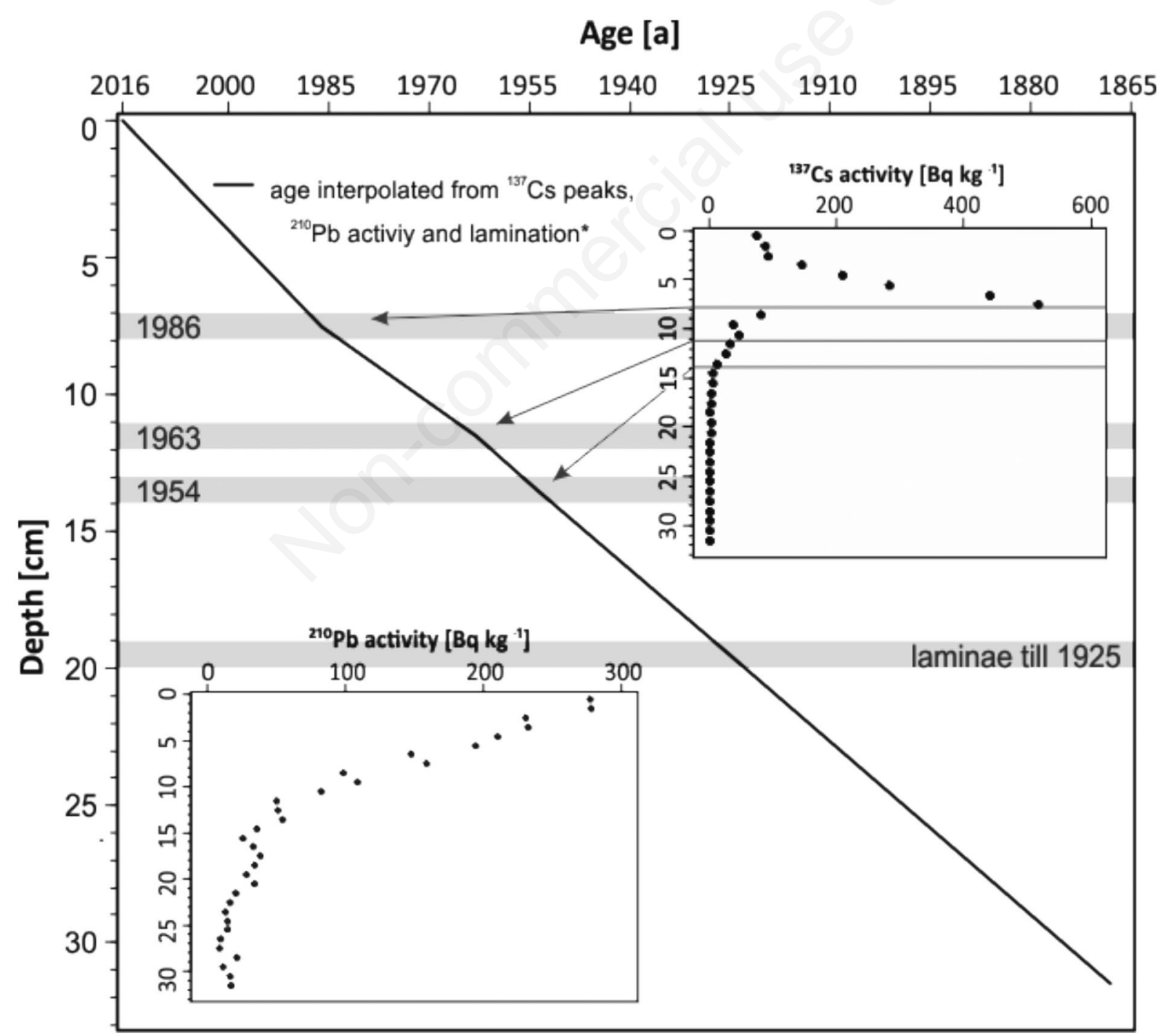

Fig. 3. Age-depth model for the GOS-07 sediment core with activity depth profiles for ${ }^{137} \mathrm{Cs}$ and ${ }^{210} \mathrm{~Pb}$. 
The sedimentologic characteristics of the three main core units are listed in Tab. 3. The sediment of unit $\mathrm{C}$ appeared dark grey with few dark streaks and no lamination. At the transition from the unstratified unit $\mathrm{C}$ to layered unit $\mathrm{B}$, a steady decline of the mean TOC/TN ratio from the maximum value of $14.6(20.5 \mathrm{~cm})$ to $9.4(17.5 \mathrm{~cm})$ indicated a loss in the input of external organic carbon from vascular plants (Fig. 5). Unit B was laminated with approx. 40 varve cycles of decreasing thickness. At the transition from unit
B (10.5) to unit A (9.5) cm, several proxies changed. Below $10.5 \mathrm{~cm}$, approximately 16 varve cycles showed regular undisturbed sedimentation. From this point upward, the sediment got darker accompanied by a steady rise in the TOC from $1.8 \mathrm{wt} \%(11.5 \mathrm{~cm})$ to reach its maximum value of $3.1 \mathrm{wt} \%(9.5 \mathrm{~cm})$. Simultaneously, the $\mathrm{CaCO}_{3}$ content declined to its minimum of $81 \mathrm{wt} \%(9.5 \mathrm{~cm})$. The well preserved core section terminated at this point with a dark $2 \mathrm{~mm}$ thick autumn-winter layer $(10.2-10.0 \mathrm{~cm})$. From

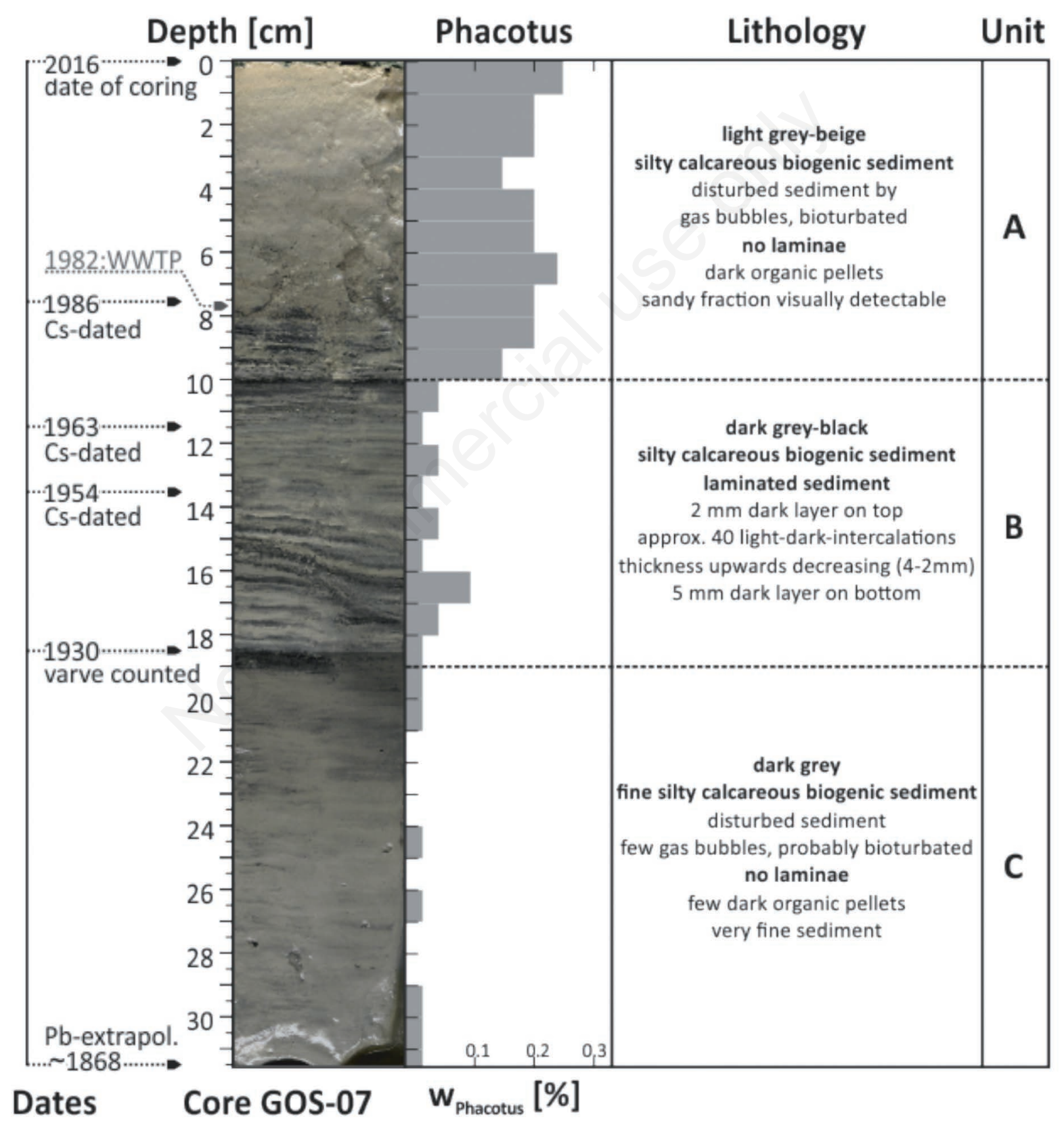

Fig. 4. Photograph of the GOS-07 core with lithology and radioisotopic dates from Lake Grosser Ostersee, and the maximum Phacotus shell abundance wPhacotus [wt\%] is given as weight per cent of dry sediment. The arrow pointing at 1982 indicates the operation start of a wastewater treatment plant (WWTP). 
$10.2 \mathrm{~cm}$ upward, there were four duplets of diffuse and unclear preserved laminations. The grey-beige unit A was found to be sandier. In the section from 10 to $8 \mathrm{~cm}$, the sand fraction increased $(+7 \mathrm{wt} \%)$ at the expense of the silt fraction. In this section, endobenthic bottom dwellers and plant macro remains were occasionally found in other cores from the same location. Additionally, cavities from gas bubbles were found at 6.0 to $7.5 \mathrm{~cm}$ depths.

The GOS-07 sediment core was $31.5 \mathrm{~cm}$ long (Fig. 4) and showed a continuous record of biogenic silty pelagic sediment with a high carbonate content of more than $87 \mathrm{wt} \% \mathrm{CaCO}_{3}$ and a low TOC content of less than $3 \mathrm{wt} \%$. The SEM sediment examination confirmed that the laminations were biochemical non-glacial varves. No allochthonous input was assumed at the deepest point of GOS, because the lake has no natural superficial inflow and the central basin is surrounded by several smaller basins (Fig. 1). This assumption was confirmed by the low mean TOC/TN ratio of 10.2 (standard deviation $\mathrm{SD}=1.8$ ) (Fig. 5).

Tab. 3. Summary of the analysis of the sediment from the GOS-07 core divided into three lithological units: A, B and C.

\begin{tabular}{lccc} 
Unit (depth) & $\mathbf{A}(0-10 \mathrm{~cm})$ & $\mathbf{B}(10-19 \mathrm{~cm})$ & $\mathbf{C}(\mathbf{1 9 - 3 1 . 5} \mathrm{cm})$ \\
Year & $2016-1970(46 \mathrm{a})$ & $1970-1927(43 \mathrm{a})$ & $1927-1868(59 \mathrm{a})$ \\
\hline Trophic state of the lake* & Meso-/Oligotrophic & Mesotrophic & Oligotrophic \\
\hline Sand fraction [\%] & $15.5 \pm 2.7$ & $7.6 \pm 1.8$ & $6.1 \pm 1.2$ \\
\hline Silt fraction [\%] & $79.2 \pm 2.2$ & $85.3 \pm 0.8$ & $86.7 \pm 0.8$ \\
\hline Clay fraction [\%] & $5.3 \pm 2.2$ & $7.1 \pm 1.1$ & $7.2 \pm 0.6$ \\
\hline Total organic carbon [\%] & $2.5 \pm 0.3$ & $2.0 \pm 0.2$ & $1.8 \pm 0.4$ \\
\hline Carbonate content [\%] & $87.7 \pm 3.3$ & $89.7 \pm 1.6$ & $90.0 \pm 2.9$ \\
\hline Phacotus shells & $3286 \pm 903$ & $327 \pm 292$ & $34 \pm 77$ \\
[Individuals $\mathrm{mg}^{-1}$ ] & & &
\end{tabular}

*Gruenert and Raeder, 2014; Melzer, 1976.

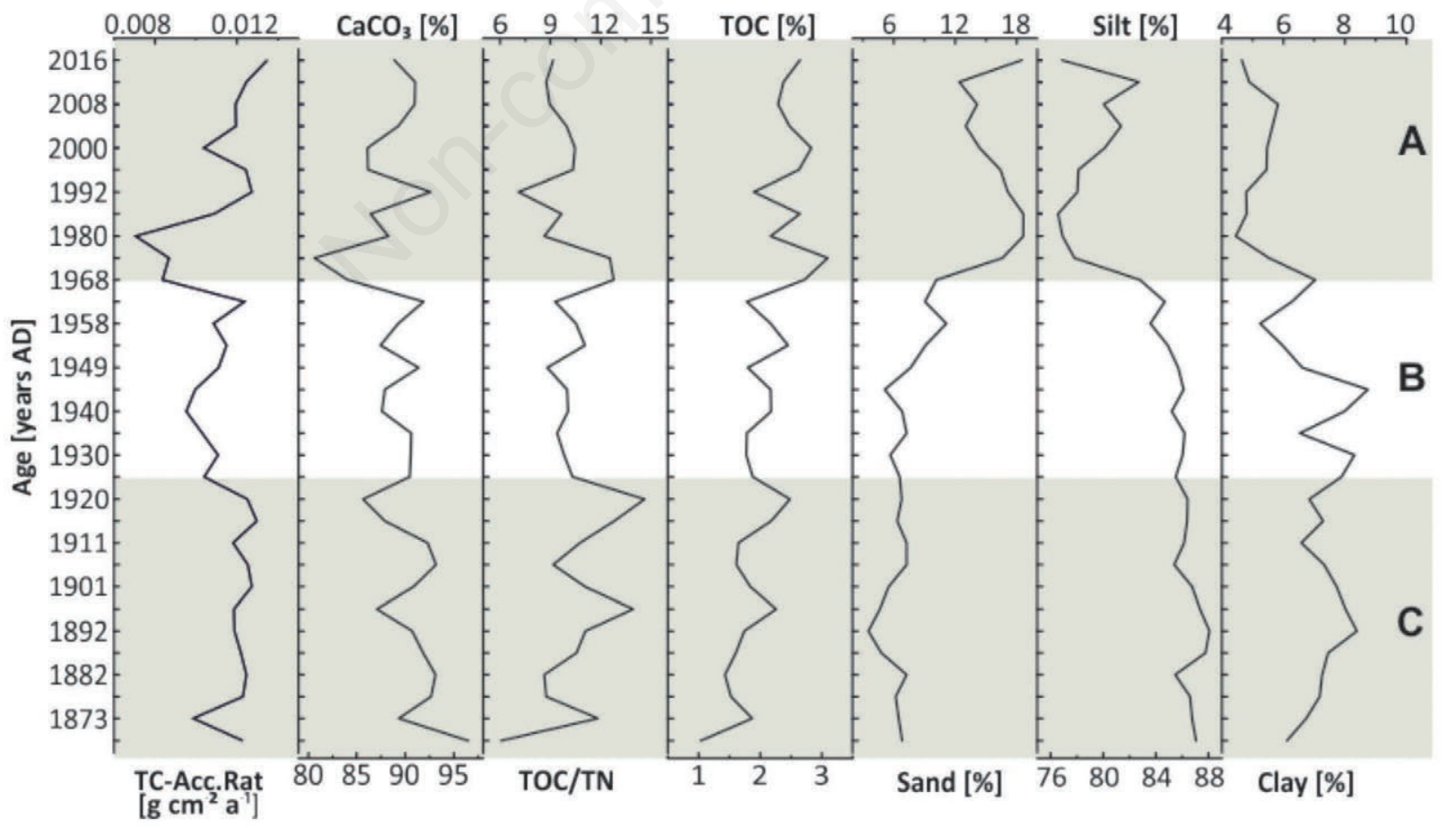

Fig. 5. Geochemical and grain size distribution profiles of the GOS-07 core from Lake Grosser Ostersee: all element content [wt- $\%$ ] is given as weigh per cent of dry sediment, and the Total Carbon Accumulation rate (TC-Acc.Rate) is given in $\left[\mathrm{g} \mathrm{C} \mathrm{m}^{-2} \mathrm{a}^{-1}\right]$. 
The $\mathrm{w}_{\text {Phacotus }}$ was determined relative to the total dry sediment mass, which ranged from 0.00 to $0.24 \mathrm{wt} \%$ (Fig. 4). The threefold division of the sediment core units was also reflected in terms of the Phacotus shell content. The units $\mathrm{C}$ and $\mathrm{B}$ contained very low amounts of Phaco-

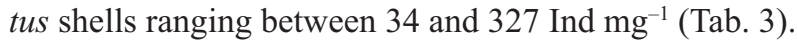
In contrast, in unit A the Phacotus shell fraction was ten times higher and accounted for $3286 \mathrm{Ind} / \mathrm{mg}$. This represented a $\mathrm{w}_{\text {Phacotus }}$ of $0.24 \mathrm{wt} \%$ of the total dry sediment mass.

Fig. 6 shows a micrograph of the counted Phacotus shells during microscopic analysis. These micrographs were used for diameter measurements and to check the shells for indications of carbonate dissolution. The mean diameter of 136 Phacotus shells from evenly distributed core depths was $13.7 \mu \mathrm{m}(\mathrm{SD}=1.7)$. This value was slightly higher than the mean diameter that was determined for living Phacotus shells in GOS (13.6 $\mu \mathrm{m}$, $\mathrm{SD}=0.9)$ (Lenz et al., 2018).

\section{DISCUSSION}

The hypothesis that Phacotus shells represent a considerable part of carbonate sequestration in lakes was confirmed in part of the samples, in which the calcite shells represented over $10 \%$ of the autochthonous calcite precipitation during the summer season in the investigated hard-water lakes.

Several aspects influence the Phacotus shell abundance in the water column and in the sediments, including (1) the difference in the specific timeframes of reference between water and sediment samples; (2) the dilution of Phacotus shell carbonate by the overall carbonate sedimentation; (3) the dissolution of Phacotus shells during sedimentation, which played a subordinate role with the exception of IGS (Fig. 2); (4) the reduction of Phacotus shell abundance in the lakes sediment, which may be caused by dissolution after deposition, such as in IGS.

For the first aspect (1), Tab. 2 shows the large discrepancy between Phacotus shell abundance in water and in sediment. This difference lies in the timeframe of reference. For example, water samples from HOP, which represent a single sampling day, contained a Phacotus shell fraction of $29 \%$ of the mean suspended calcite, whereas in the sediment samples representing approximately 15 years of carbonate sedimentation, Phacotus shells represented only $2.28 \%$ of the total carbonate sediment.

The second aspect (2) indicates that the low Phacotus fractions in lake sediments were caused by 'dilution'. The Phacotus populations showed strong growth and high abundances in midsummer (Fig. 2), but these periods were generally short (Koschel et al., 1987; Krienitz et al., 1993; Gruenert and Raeder, 2014; Lenz et al., 2017). Therefore, the contribution of Phacotus shells to the carbonate sediment remains low in comparison to the overall autochthonous biogenic calcite. In spring and late summer, the autochthonous carbonate precipitation induced by diatoms and cyanobacteria blooms (Dittrich and Obst, 2004) is the source of most sedimented carbonate in lakes (Kelts and Hsü, 1978). However, charaphyceans, their crushed stem casts, and oogonia can also be transported as suspended particles from the littoral zone as a result of wind induced wave activity (Emi, 2001), and they can contribute to the carbonate sequestration in the deepest lake sectors. This was especially the case in GOS, where the GOS-07 sediment core contained a low Phacotus shell content of not more than $0.24 \%$ which equals an amount of 4593 shells per mg. These low Phacotus contents at this location might have resulted from a combination of several factors. The oligotrophic lake with limited primary production showed a high abundance of the picocyanobacterium Synechococcus (Ruber et al., 2018), which contributed to intense autochthonous carbonate precipitation (Dittrich $e t$

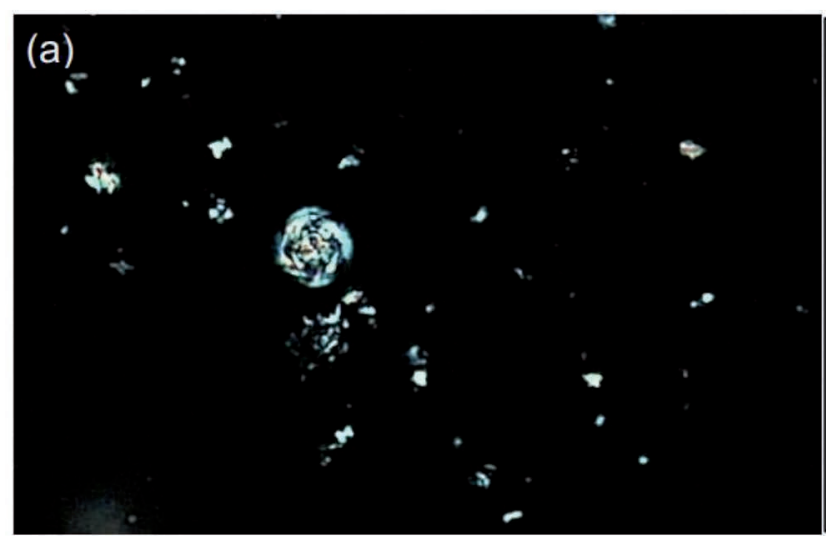

(b)

Fig. 6. Micrograph of sediment sample from $0.5 \mathrm{~cm}$ of the GOS- 07 core under crossed nicols (a) and the corresponding picture for diameter measurements after processing with ImageJ Fiji software. 
al., 2003; Dittrich et al., 2004), resulting in an extraordinary high total carbonate content in the sediment $(>89 \%)$. In addition to the generally moderate Phacotus population, the sediment had a very low Phacotus content. Nevertheless, Phacotus shells were always present over the complete depth of the sediment core. From 1970, the Phacotus shell abundance rose to the maximum value of $0.24 \%$ in the topmost sediment layer. The lowest Phacotus shell contents were found in the deepest core in unit $\mathrm{C}$, not exceeding $0.02 \%$ which equals an amount of less than 290 shells per mg. From this point upward, the Phacotus shell content gradually increased (Fig. 4).

Aspect (3) indicates that Phacotus shells dissolve in the water column during sedimentation. This aspect was not confirmed and seemed unlikely in the majority of the investigated lakes. For example the groundwater-fed and relatively cold pre-alpine GOS is characterised by constant high alkalinity with permanent carbonate super saturated conditions. In contrast, in IGS, practically no shells were detected in the sediment, although in the epilimnion, numerous Phacotus shells had been observed (Fig. 2b). Shells from sediment trap experiments at the bottom of IGS (Lenz et al., 2020) showed partly dissolved Phacotus shells, which was interpreted as an evidence of the carbonate dissolution conditions in the water.

However, aspect (4), which is related to the dissolution of carbonate particles, has to be considered in the sediment. Under oxic conditions, which were indicated by living bottom dwellers found in the bioturbated sediment core sections, carbonates are likely to dissolve, because the decomposition of organic matter provides free protons that lead to the dissolution of carbonate particles (Müller et al., 2006). For example, based on a sedimentation rate of $0.2 \mathrm{~mm} \mathrm{a}^{-1}$, the residence time for sedimented carbonates in the oxic sediment zone of GOS-07 sediment core was found to be approximately two to three years. Therefore, carbonate dissolution was likely to occur in the topmost sediment of GOS. However, the embedded Phacotus shells were not alterated. The value of their diameter over the complete depth of the sediment core remained constant at $13.7 \mu \mathrm{m}(\mathrm{SD}=1.7)$, which was also within the same range as the living Phacotus shells that were analysed from the water column (Lenz et al., 2018). Furthermore, light microscopic images showed that, in the epilimnion of GOS, small calcite particles $(<2 \mu \mathrm{m})$ were present in abundance, which were not observed during microscopic examination of the lakes' sediment. This result is in accordance with the findings of Müller et al. (2006), which proposed that dissolution in aerated hardwater lake sediments preferentially take place at the expense of smaller calcite crystals, due to their elevated weight-specific surface area, instead of reducing the amount of Phacotus shells.

\section{CONCLUSIONS}

The abundance of Phacotus shell in lacustrine sediments is mainly affected by total carbonate sedimentation. Although the dynamic population development of Phacotus in the water column temporally provides the Phacotus carbonate contents with $59 \%$ of the total suspended carbonate, in the sedimentary record, only low total sediment carbonate contents could be observed. Dissolution can reduce the number of Phacotus shells present in the water column before they reach the ground. However, once embedded in the anoxic section of the basinal sediment, shells were found to be preserved in the investigated sediment cores with shell diameters in the same range of recent living Phacotus individuals.

Quantitative data are necessary to accurately define the 'Phacotus-rich' sediments as described by (Haberzettl et al., 2007; Jouve et al., 2013; Lagerheim, 1902) and their formation mechanisms. The two most probable mechanisms are supposed to be formation as a result of primary concentration in the water column due to wind action in littoral zones and formation resulting from the secondary concentration caused by the dissolution of smaller carbonate particles around the Phacotus shells.

\section{ACKNOWLEDGMENTS}

Funding has been provided by the Bavarian State Ministry of the Environment and Consumer Protection, Project Nr. TLK10U-6627. We are grateful to Prof. Tanja Gschlöß1 for her continuous support of this project. We also thank Simone Rost for help in the laboratory and with the microscopic analysis. Further thanks are due to Alfred Lück for the gamma radiation measurements and Irene Brunner who supervised the sediment TOC and grainsize analysis at Eawag in Dübendorf, Switzerland.

\section{REFERENCES}

Appleby PG, 2001. Chronostratigraphic techniques in recent sediments, p. 171-203. In: W.M. Last, J.P. Smol and H.J.B. Birks (eds), Tracking environmental change using lake sediments: Basin analysis, coring and chronological techniques. Kluwer, Dordrecht.

Auerswald K, Geist J, 2018. Extent and causes of siltation in a headwater stream bed: catchment soil erosion is less important than internal stream processes. Land Degrad. Develop. 29:737-748.

Bollmann J, Brabec B, Cortés MY, Geisen M, 1999. Determination of absolute coccolith abundances in deep-sea sediments by spiking with microbeads and spraying (SMS-method). Mar. Micropaleontol. 38:29-38.

Bordiga M, Bartol M, Henderiks J, 2015. Absolute nannofossil abundance estimates: Quantifying the pros and cons of dif- 
ferent techniques. Rev. Micropaleontol. 58:155-165.

Dittrich M, Kurz P, Wehrli B, 2004. The role of autotrophic picocyanobacteria in calcite precipitation in an oligotrophic lake. Geomicrobiol. J. 21:45-53.

Dittrich M, Müller B, Mavrocordatos D, Wehrli B, 2003. Induced calcite precipitation by cyanobacterium synechococcus. Acta Hydroch. Hydrob. 31:162-169.

Dittrich M, Obst M, 2004. Are picoplankton responsible for calcite precipitation in lakes? AMBIO: J. Hum. Env. 33:559-564.

Emi I, 2001. Application of stable isotope techniques to inorganic and biogenic carbonates, p. 351-371. In: W.M. Last and J.P. Smol (eds), Tracking Environmental Change using Lake Sediments: Physical and Geochemical Methods. Kluwer, Dordrecht.

Gruenert U, Raeder U, 2014. Growth responses of the calciteloricated freshwater phytoflagellate Phacotus lenticularis (Chlorophyta) to the $\mathrm{CaCO} 3$ saturation state and meteorological changes. J. Plankton Res. 36:630-640.

Guiry MD, 2019. AlgaeBase: Phacotus lenticularis (Ehrenberg) Diesing, World-wide electronic publication. Nat. Univ. of Ireland, Galway. Accessed on: 4 Aug 2019. Available from: http://www.algaebase.org/search/species/detail/?species_id $=34576$

Haberzettl T, Corbella H, Fey M, Janssen S, Lücke A, Mayr C, Ohlendorf C, Schäbitz F, Schleser GH, Wille M, Wulf S, Zolitschka B, 2007. Lateglacial and Holocene wet - dry cycles in southern Patagonia: Chronology, sedimentology and geochemistry of a lacustrine record from Laguna Potrok Aike, Argentina. Holocene 17:297-310.

Jouve G, Francus P, Lamoureux S, Provencher-Nolet L, Hahn A, Haberzettl T, Fortin D, Nuttin L, 2013. Microsedimentological characterization using image analysis and $\mu-\mathrm{XRF}$ as indicators of sedimentary processes and climate changes during Lateglacial at Laguna Potrok Aike, Santa Cruz, Argentina. Quaternary Sci. Rev. 71:191-204.

Kelts K, Hsü KJ, 1978. Freshwater carbonate sedimentation. In: A. Lerman (ed), Lakes. Springer New York, New York, NY, 295-323.

Koch C, Young JR, 2007. A simple weighing and dilution technique for determining absolute abundances of coccoliths from sediment samples. J. Nannoplankton Res. 29:67-69.

Koschel R, Proft G, Raidt H, 1987. [Phacotus-Massenentwick- lungen - eine Quelle des autochthonen Kalkeintrages in Seen].[Article in German]. Limnologica 18:457-459.

Koschel R, Raidt H, 1988. [Morphologische Merkmale der Phacotus-Hüllen in Hartwasserseen der Mecklenburger Seenplatte].[Article in German]. Limnologica 19:13-25.

Krienitz L, Koschel, Giering B, Casper SJ, Hepperle D, 1993. Phenomenology of organismic calcite precipitation by Phacotus in hardwater lakes and ponds of northeastern Germany. Verh. Int. Verein. Limnol. 170-174.

Lagerheim G, 1902. [Untersuchungen über fossile Algen, I, II].[Article in German]. Geologiska Föreningen i Stockholm Förhandlingar. 24:475-500.

Lenz S, Geist J, Raeder U, 2020. Representative monitoring of calcifying alga Phacotus lenticularis in lentic ecosystems. J. Limnol. 79:1946. doi: 10.4081/jlimnol.2020.1946

Lenz S, Gruenert U, Geist J, Stiefel M, Lentz M, Raeder U, 2018. Calcite production by the calcifying green alga $P h a-$ cotus lenticularis. J. Limnol. 77:1692. doi: 10.4081/jlimnol. 2018.1692

McGowan S, Anderson NJ, Edwards ME, Langdon PG, Jones VJ, Turner S, van Hardenbroek M, Whiteford E, Wiik E, 2015. Long-term perspectives on terrestrial and aquatic carbon cycling from palaeolimnology. WIREs Water 3:211-234.

Müller B, Wang Y, Wehrli B, 2006. Cycling of calcite in hard water lakes of different trophic states. Limnol. Oceanogr. 51:1678-1688.

Rasband WS, 2016. ImageJ: public domain Java image processing program. National Institutes of Health, Bethesda, MA, USA.

Ruber J, Geist J, Hartmann M, Millard A, Raeder U, Zubkov M, Zwirglmaier K, 2018. Spatio-temporal distribution pattern of the picocyanobacterium Synechococcus in lakes of different trophic states: A comparison of flow cytometry and sequencing approaches. Hydrobiologia 811:77-92.

Schlegel I, Koschel R, Krienitz L, 1998. On the occurrence of Phacotus lenticularis (Chlorophyta) in lakes of different trophic state. Hydrobiologia 369-370:353-361.

Stabel H-H, 1986. Calcite precipitation in Lake Constance: Chemical equilibrium, sedimentation, and nucleation by algae1. Limnol. Oceanogr. 31:1081-1094.

Utermöhl H, 1958. [Zur Vervollkommnung der quantitativen Phytoplankton-Methodik].[Article in German]. E. Schweizerbart'sche, Stuttgart. 